\title{
Word Order of Persian and English: A Processing-Based Analysis
}

\author{
Mehri Izadi ${ }^{1, \text { *, Maryam Rahimi² }}$ \\ ${ }^{1}$ Department of English Language, Chabahar Maritime University, Chabahar, Iran \\ ${ }^{2}$ Department of English Language and Literature, University of Sistan \& Balouchestan, Zahedan, Iran
}

Email address:

izadimi@yahoo.com (M. Izadi), maryam.rahimi@gmail.com (M. Rahimi)

\section{To cite this article:}

Mehri Izadi, Maryam Rahimi. Word Order of Persian and English: A Processing-Based Analysis. Education Journal. Vol. 4, No. 1, 2015, pp. 37-43. doi: 10.11648/j.edu.20150401.18

\begin{abstract}
Word order refers to analyzing the order of languages syntactic constituent to find out the areas of their similarities and differences. In the present study, we intend to elaborate Persian and English word order mainly based on Dryer (1992) and Dabir Moghaddam (2001). Our research material includes examples driven from 26 orders. We studied these orders in order to present a clearer picture of correlations and diversities between the two languages. Research findings reveal that although Persian is an SOV language and English has the SVO order, these languages represent similarities in half of the 26 orders provided. As to differences, they are different in the application of adposition, noun and relative clause, want and verb, content verb and auxiliary, question particle and sentence, adverbial subordinator and clause, etc.
\end{abstract}

Keywords: Word Order, Persian Language, English Language, Contrastive Study

\section{Introduction}

Word order is the analysis of the order of the syntactic constituents of a language, and that how different languages would employ different orders (Tallerman, 2005). The discrepancies and similarities between orders in different syntactic domains are a matter of interest for linguists (Tallerman, 2005). Some languages are relatively inflexible in their word order. Thus, in order to convey grammatical information, their speakers have to rely on the order of constituents. Other languages are more flexible and convey grammatical information via inflection, case marking, or other markers. This shows that most languages have a preferred word order and use it most frequently than other word orders (Johnson, 2008). Based on Tallerman (2005) there are 6 possible constituent word orders for the world languages:

1. Subject + verb + object (i.e. SVO): including English, the Romance languages, Bulgarian, Macedonian, Chinese and Swahili,

2. Subject + object + verb (SOV): the prototypical Japanese, Mongolian, Basque, Turkish, Korean, the Indo-Aryan languages, the Dravidian languages, Persian, Latin and Quechua,

3. Verb + subject + object (VSO): Classical Arabic, the
Insular Celtic languages, and Hawaiian,

4. Verb + object + subject (VOS): Fijian and Malagasy,

5. Object + subject + verb (OSV): Xavante and Warao,

6 . Object + verb + subject (OVS): Hixkaryana.

Many languages of the world are either SVO or SOV. The third significant word order which is much smaller than the two is VSO word order. The three remaining orders are rare.

English is mostly an SVO language and has a strict word order in which words can be presented in sentences. This order is exemplified below:

The researchers sent their manuscripts to the journal (Wallwork, 2011: 21).

Here, we have subject (the researcher), verb (sent), direct object (their manuscripts) and indirect object (to the journal). If these parts of speech appear in a different word order, it would be difficult for the readers to get the meaning fully. Thus, the key is to keep these elements as close to each other as possible (ibid.). Whereas English sentences normally put the subject at the beginning of sentences, followed by the predicate, there are sentences in which the verbs come initially, such as imperative sentences like: Beware of dog! Here, we do not have any subject. In these cases English examples still conform to English grammar, and do not allow random placement of subject, verb and object. This means that word order is crucial in English language because it has a fixed word order (Gill, 2010). By adding an indirect object 
the word order will be more complicated. Most of the English sentences have adverbials. The problem for the English learner is that some adverbials can be placed differently within the sentence, while other adverbials must appear in one place only; e.g. we can say both: "I very quickly did my homework" and "I did my homework very quickly", while we can say only "I did my homework in a hurry". Examples like these reveal that English learners who want to have a correct word order should ask a native speaker or consult a good usage guide such as Swan's Modern English Usage or search the sentences in the web (Shoebottom, n. d.).

However, as far as word order is concerned, Persian is more flexible and its word order is relatively free. Some of these orders are more marked than other orders, but all of them can be permissible (Ramsay, Ahmed \& Mirzaiean, 2005). Persian can have free word order, because Persian parts of speech are totally unambiguous. Moreover, prepositions and the accusative marker help to remove ambiguity (Oranski, 2007). Also, case endings like different suffixes allow speakers to permute word order (Ramsay et al., 2005). This feature enhances expressiveness and more information load can be driven from each of its sentence. Verb endings can provide information about the tense and subject of a sentence. The verb /mi-ra-v-am/ can mean "I am going". In Persian subjects can be freely omitted, there are not any distinctions between nouns and noun phrases (Ramsay et al., 2005), the main clause is located before a subordinate clause. Modifiers usually come after the nouns which they modify. The question particle $/ \hat{a} y \hat{a} /$, which is used in yes/no questions appears at the beginning of sentences. Contrary to many languages which use SVO, Persian can use prepositions. The object marker, "râ", precedes its direct object (Oranski, 2007).

The present project deals with the differences and similarities between the word order of Persian and English language. This study provides findings about word order status of these languages through the analyses and recognition of their behavioral patterns and their specific characterizations. The project found its way on the basis of Dryer (1992) and Dabirmoghaddam (2001) works on word order. We compared the two languages according to the criteria of their distinctive variations based on 26 orders, each with two examples. We demonstrated how they behave by classifying them into two different charts, and analyzed their word order. Further, we provided the whole representation of the data gathered for the concerned languages. The table can show in which orders the two languages correlate, or signify differences. Finally, we evaluated the results of the data on the basis of our observations, and showed the similarities and differences among the concerned languages as well. Then, it will be possible to classify those similar orders that show correlations in their word order and to distinguish them from those orders that reveal different patterns.

The 26 orders that were the basis of our study are as follows: (They are derived from Persian language, and are given phonetically. Then, they will be translated into English

in subsequent parts of the paper for a clearer comparison)

1. Adposition type
/boŝâ̂b râ ruye miz gozâstam/
/man dar hayât zamin xordam/

2. Order of noun and relative clause /doxtari ke bâ somâ ?âmad/

/lebâsi ke sabz rang ?ast/

3. Order of noun and genitive

/ŝalvâre pedar duxte ŝod/

/qazâye baĉce rixt/

4. Order of adjective and standard in comparative construction

/mina zibâtar ?az zahrâ ?ast/

/?u kuĉaktar ?az ?ali ?ast/

5. Order of verb and adpositional phrase

/man hamiŝe be ?u fekr mikonam/

/fardâ ?az mosâferat mi?âyam/

6. Order of verb and manner adverb

/man geryân ?âmadam/

/man bâ xoŝhâli ?u râ busidam/

7. Order of copula and predicate

/havâ ?âftâbi ?ast/

/pedare ?u keŝâvarz ?ast/

8. Order of 'want ' + verb

/mixâham be xâne?at biyâyam/

/to mixâhi dâstân râ benevisi/

9. Order of content verb and auxiliary verb /mâ mitavânim bedavim/

/man mitavânam bexânam/

10. Order of question particle and sentence

/?âyâ to midâni?/

/?âyâ ?ânhâ mariz hastand?/

11. Order of adverbial subordinator and clause

/?vaqti ke ?u râ didi/

/?hengâmi ke be xâne ?âmadi/

12. Order of article and noun

/doxtari ?âmad/

/ĉerâqi roŝan ŝod/

13. Order of verb and subject

/man xâbidam/

/doxtar raft/

14. Order of numeral and noun

/çahâr livân ŝekast/

/do pesar raftand/

15. Order of tense/aspect affix and verb stem /be xâne miravam/

/?u râ mibinam/ 
16. Order of affix and noun

/pedaram ?âmad/

/be xâne?aŝ raftam/

17. Order of verb and object

/dâstân râ xândam/

/baĉce râ didam/

18. Order of tense/aspect auxiliary verb

/?u ketâb xânde ?ast/

/man ?u râ dide?am/

19. Order of negative auxiliary and verb stem /nemitavânam be kelâs biyâyam/

/be ?ânjâ naxâham raft/

20. Order of complementizer and sentence

/fekr mikardam ke ?u rafte ?ast/

/midânestam ke mi?âyad/

21. Order of plural word and noun

/baĉcehâ? âmadand/

/darhâ baste ŝod/

22. Order of noun and adjective

/doxtare zibâ ?âmad/

/mâdare mehrabân raft/

23. Order of demonstrative and noun

/?in golhâ zibâ hastand/

/?ân doxtar râ didam/

24. Order of intensifier and adjective /mohammad xeili sangin ?ast/

/?u kami caq ast/

25. Order of verb and negative particle

/nâme râ naneveŝtam/

/qazâ râ naxordam/

26. Order of tense/aspect particle and verb

/?u mixâhad bedavad/

/?agar be madrese beravam/

\section{Word Order in English and Persian}

By the use of the 26 orders in the introduction we start to investigate the word order status of each language in turn. First, we provide the Persian examples followed by their glosses, and then we present the corresponding English equivalents for each order. There are two tables representing the word order of Persian and English separately. Then table (3) is given based on our observations that reports helpful information about their characteristics. Finally, we deal with each language in detail:

$\begin{array}{llll}\text { 1) boŝâb râ } & \text { ru-y-e } & \text { miz } & \text { gozaŝt-am } \\ \text { plate OM } & \text { on-EP-GEN } & \text { table } & \text { put.PAST-1SG } \\ \text { "I put the plate on the table." } & & \\ \text { man dar hayât zamin } & & \text { xord-am }\end{array}$

I in yard ground eat.PAST-1SG "I fell down in the yard"

2) doxtar-i ke bâ soma ?âmad girl-REST that with you come.PAST.3SG

"The girl who came with you"

lebâs-i ke sabz rang ?ast clothes-REST that green color be.PRES.COP.3SG "The clothes which is green"

3) salvâr-e pedar duxt-e sod-e ?ast trousers-GEN father sew-PAST-PP become-PAST-

PP be.PRES.AUX.3SG

"The father`s trousers are sewn."

qazâ-y-e baĉce rixt food-EP-GEN child spill.PAST.PASSIVE.3SG

"The child`s food spilled."

4) mina zibâ-tar ?az zahrâ ?ast

Mina beautiful-COMP from Zahra be.PRES.COP.3SG

"Mina is more beautiful than Zahra."

?u kuĉek-tar ?az ?ali ?ast

he small-COMP from Ali be.PRES.COP.3SG

"He is smaller than Ali."

5) man hamiŝe be ?u fekr mi-kon-am I always to he thought IMP-do.PRES-1SG "I always think about him."

fardâ ?az mosafera mi-?â-y-am tomorrow from trip IMP-come.PRES-EP-1SG "Tomorrow I come back from my trip."

6) man geryân ?âmad-am I crying come.PAST-1SG "I came crying."

$\begin{array}{lllll}\text { man } & \text { bâ } & \text { xoŝhhali ?u } & \text { râ } & \text { busid-am } \\ \text { I } & \text { with } & \text { happiness } & \text { he } & \text { OM }\end{array}$
kiss.PAST-1SG

"I kissed him happily."

7) havâ ?âftâbi ?ast weather sunny be.PRES.COP.3SG "The weather is sunny."

pedar-e ?u keŝâarz ?ast father-GEN he farmer be.PRES.COP.3SG "His father is a farmer."

8) mi-xâh-am be xâne-?at bi-y-â-y-am IMP-want.PRES-1SG to home-you.CLIT SUBEP-come.PRES-EP-1SG

"I want to come to your house."

\begin{tabular}{lllll} 
to mi-xâh-i dâstân & râ & \multicolumn{2}{l}{ be-nevis-i } \\
you IMP-want.PRES-2SG & story & OM & SUB- \\
write PRES-2SG & & & &
\end{tabular}


"You want to write the story."

9) mâ mi-tavân-im be-da-v-im

we IMP-can.PRES.AUX-1PL SUB-run.PRES-EP-1PL

"We can run."

man mi-tavân-am be-xân-am

I IMP-can.PRES.AUX-1SG SUB-read.PRES-1SG

"I can read."

10) ?âyâ to mi-dân-i

whether you IMP-know.PRES-2SG

"Do you know?"

?âyâ ?ânhâ mariz hast-and

whether they sick be.PRES.COP-3PL

"Are they sick?"

11) vaqti ke ?u râ did-i

when that he OM see.PAST-2SG

"When you saw him"

hengâmi ke be xâne ?âmad-i

when that to home come.PAST-2SG

"When you came home"

12) doxtar-i ?âmad

girl-INDEF come.PAST.3SG

"A girl came."

ĉerâq-i roŝan ŝod

light-INDEF on become.PAST.PASSIVE.COP.3SG

"A light turned on."

13) man xâbid-am

I sleep.PAST-1SG

"I slept."

doxtar raft

girl go.PAST.3SG

"The girl went."

14) ĉahâr livân ŝekast

four glass break.PAST.PASSIVE.3SG

"Four glasses broke."

do pesar raft-and

two boy go.PAST-3SG

"The two boys went."

15) be xâne mi-ra-v-am

to home IMP-go.PRES-EP-1SG

"I am going to home."

?u râ mi-bin-am

he OM IMP-see.PRES-1SG

"I see him."

16) pedar-am ?âmad

father-I.CLIT come.PAST.3SG

"My father came."

$$
\begin{array}{ll}
\text { be xâne-?aŝ } & \text { raft-am } \\
\text { to home-he.CLIT } & \text { go.PAST-1SG } \\
\text { "I went to his house." } &
\end{array}
$$

17) dâstân rân nând-am

story OM read.PAST-1SG

"I read the story."

baĉce râ did-am

child OM see.PAST-1SG

"I saw the child."

18) ?u ketab xând-e ?ast

he book read-PAST-PP be.PRES.AUX.3SG

"He has read a book."

man ?u râ did-e-?am

I he OM see-PAST-PP-AUX.1SG

"I have seen him."

19) ne-mi-tavân-am be kelâs bi-y-â-y-am

NEG-IMP-can.PRES.AUX-1SG to class SUB-EP-come.PRES-EP-1SG

"I cannot come to class."

be ?ânja na-xâh-am raft

to there NEG-want.PRES.AUX-1SG go.PAST

"I won`t go there."

20) fekr mi-kard-am ke ?u $\begin{array}{cc}\text { raft-e } & \text { ?ast } \\ \text { IMPought } & \text { IMP.PAST-1SG that he }\end{array}$ go-PAST-PP be.PRES.AUX.3SG

"I thought that he`s gone."

mi-dânest-am ke mi-?â-y-ad

IMP-know.PAST-1SG that IMP-come.PRES-EP-3SG

"I knew that he would come."

21) baĉce-hâ ?âmad-and

child-PL come.PAST-3PL

"The children came."

dar-hâ baste sood

door-PL close-PAST-PP become.PAST.AUX.3SG

"The doors got closed."

22) doxtar-i zibâ ?âmad

girl-GEN beautiful come.PAST.3SG

"The beautiful girl came."

mâdar-i mehrabân raft

mother-GEN kind

go.PAST.3SG

" The kind mother went."

23) ?in gol-hâ zibâ hast-and this flower-PL beautiful be.PRES.COP-3SG

"These flowers are beautiful."

?ân doxtar râ did-am

that girl OM see.PAST-1SG

"I saw that girl." 
24) mohammad xeyli sangin ?ast Mohammad very heavy be.PRES.COP.3SG "Mohammad is very heavy."

$\begin{array}{llll}\text { ?u } & \text { kam-i câq } & \text { ?ast } & \\ \text { he } & \text { little-INDEF } & \text { fat } & \text { be.PRES.COP.3SG }\end{array}$

"He is a little fat."

25) nâme râ na-neveŝt-am

letter OM NEG-write.PAST-1SG

"I didn`t write the letter."

$\begin{array}{lll}\text { qazâ } & \text { râ } & \text { na-xord-am } \\ \text { food } & \text { OM } & \text { NEG-eat.PAST-1SG }\end{array}$

"I didn`t eat the food."

26) ?u mi-xâh-ad

he IMP-want.PRES-3SG

be-da-v-ad

"He wants to run."

$\begin{array}{lll}\text { ?agar } & \text { be } & \text { madrese be-ra-v-am } \\ \text { if } & \text { to } & \text { school SUB-go.PRES-EP-1SG }\end{array}$

"If I go to school"

According to the given discourse patterns, Table (1) shows the orders of different parts of speech in Persian language, and similarly Table (2) shows these features in English as well.

Table 1. Persian word order

\begin{tabular}{|c|c|c|}
\hline & Orders & Persian \\
\hline 1 & adposition type & $\mathrm{PREP}+\mathrm{N}$ \\
\hline 2 & noun and relative clause & $\mathrm{N}+\mathrm{REL} \mathrm{CL}$ \\
\hline 3 & noun and genitive & $\mathrm{N}+\mathrm{GEN}$ \\
\hline 4 & $\begin{array}{l}\text { adjective and standard in comparative } \\
\text { construction }\end{array}$ & $\mathrm{ADJ}+\mathrm{COMP}$ \\
\hline 5 & verb and adpositional phrase & ADP.PH+V \\
\hline 6 & verb and manner adverb & M.ADV+V \\
\hline 7 & copula and predicate & $\mathrm{PRE}+\mathrm{COP}$ \\
\hline 8 & 'want ' + verb & $\mathrm{WANT}+\mathrm{V}$ \\
\hline 9 & content verb and auxiliary verb & AUX.V+CON.V \\
\hline 10 & question particle and sentence & QU.PRT+S \\
\hline 11 & adverbial subordinator and clause & ADV.SUB+CL \\
\hline 12 & article and noun & $\mathrm{N}+\mathrm{ART}$ \\
\hline 13 & verb and subject & $\mathrm{S}+\mathrm{V}$ \\
\hline 14 & numeral and noun & $\mathrm{NUM}+\mathrm{N}$ \\
\hline 15 & tense/aspect affix and verb stem & $\mathrm{AFF}+\mathrm{VS}$ \\
\hline 16 & possessive affix and noun & $\mathrm{N}+$ POSS.AFF \\
\hline 17 & verb and object & $\mathrm{O}+\mathrm{V}$ \\
\hline 18 & tense/aspect auxiliary verb & $\mathrm{V}+\mathrm{AUX}$ \\
\hline 19 & negative auxiliary and verb stem & NEG.AUX+V \\
\hline 20 & complementizer and sentence & $\mathrm{COMPL}+\mathrm{S}$ \\
\hline 21 & plural word and noun & $\mathrm{N}+\mathrm{PL}$ \\
\hline 22 & noun and adjective & $\mathrm{N}+\mathrm{ADJ}$ \\
\hline 23 & demonstrative and noun & $\mathrm{DEM}+\mathrm{N}$ \\
\hline 24 & intensifier and adjective & $\mathrm{INT}+\mathrm{ADJ}$ \\
\hline 25 & verb and negative particle & NEG.PRT +V \\
\hline 26 & tense/aspect particle and verb & $\mathrm{PRT}+\mathrm{V}$ \\
\hline
\end{tabular}

Table 2. English word order.

\begin{tabular}{ll|l}
\hline & Orders & English \\
\hline 1 & adposition type & PREP+N \\
2 & noun and relative clause & N+REL CL \\
3 & noun and genitive & GEN+N \\
4 & adjective and standard in comparative & COMP+ADJ \\
5 & construction & V+ADP.PH \\
6 & verb and adpositional phrase & V+M.ADV \\
7 & verb and manner adverb & COP+PRE \\
8 & copula and predicate & WANT+V \\
9 & 'want ' + verb & AUX.V+CON.V \\
10 & content verb and auxiliary verb & QU.PRT+S \\
11 & advertion particle and sentence & ADV.SUB+CL \\
12 & article and noun & ART+N \\
13 & verb and subject & S+V \\
14 & numeral and noun & NUM+N \\
15 & tense/aspect affix and verb stem & VS+AFF \\
16 & possessive affix and noun & POSS.AFF+N \\
17 & verb and object & V+O \\
18 & tense/aspect auxiliary verb & AUX+V \\
19 & negative auxiliary and verb stem & NEG.AUX+V \\
20 & complementizer and sentence & COMPL+S \\
21 & plural word and noun & N+PL \\
22 & noun and adjective & ADJ+N \\
23 & demonstrative and noun & DEM+N \\
24 & intensifier and adjective & NEG.PRT+V \\
25 & verb and negative particle & PRT+V \\
26 & tense/aspect particle and verb & \\
\hline & & \\
\hline
\end{tabular}

\section{Results and Discussion}

With detailed analysis of the concerned languages, Table (3) can be proposed. It is the gist representation of the data gathered for their word order. These languages reveal some similarities and differences in different aspects. Accordingly, it can almost be a good representation of differences and similarities between Persian and English word order

Based on the given examples, Persian and English have the same word orders in examples numbered: $1,2,8,9,10,11$, $13,14,19,20,21,23,24,25$, and 26. These similarities are given in turn:

- Adposition type in that preposition comes before a noun,

- Noun and relative clause, in that nouns precede the REL.CL,

- 'Want' + verb: In all the languages 'want' precedes the verb,

- Content verb and auxiliary verb, in that CON.V comes after the AUX,

- Question particle and sentence, in that QU.PRT precedes the sentence,

- Adverbial subordinator and clause, in that the ADV.SUB comes before the clause,

- Verb and subject, in that verbs proceed their subjects,

- Numeral and noun, in that nouns come after their NUM,

- Negative auxiliary and verb, in that NEG. AUX precedes its V.

- Complementizer and sentence, in that complementizers come at the beginning of sentences,

- PL marker and noun, in that PL marker proceeds its noun, 
- Demonstrative and noun, in that nouns proceed their demonstratives,

- Intensifier and adjective, in that INT comes before its ADJ

- Verb and negative particle, in that NEG.PRT precedes the V.

- And finally, tense/ aspect particle and verb, in that $\mathrm{V}$ follows its PRT.

Dealing with differences, it is obviously noticeable that the remaining orders have shown significant differences. Table (3) below testifies to what we have mentioned earlier in this study. The gray parts are the points of difference between the two languages:

Table 3. English and Persian word order.

\begin{tabular}{|c|c|c|}
\hline & Persian & English \\
\hline 1 & $\mathrm{PREP}+\mathrm{N}$ & $\mathrm{PREP}+\mathrm{N}$ \\
\hline 2 & $\mathrm{~N}+\mathrm{REL} \mathrm{CL}$ & $\mathrm{N}+\mathrm{REL}$ CL \\
\hline 3 & $\mathrm{~N}+\mathrm{GEN}$ & $\mathrm{GEN}+\mathrm{N}$ \\
\hline 4 & $\mathrm{ADJ}+\mathrm{COMP}$ & $\mathrm{COMP}+\mathrm{ADJ}$ \\
\hline 5 & ADP.PH+V & V+ADP.PH \\
\hline 6 & M.ADV+V & V+M.ADV \\
\hline 7 & $\mathrm{PRE}+\mathrm{COP}$ & $\mathrm{COP}+\mathrm{PRE}$ \\
\hline 8 & $\mathrm{WANT}+\mathrm{V}$ & WANT+V \\
\hline 9 & AUX+CON.V & AUX.V+CON.V \\
\hline 10 & QU.PRT+S & QU.PRT+S \\
\hline 11 & ADV.SUB+CL & ADV.SUB+CL \\
\hline 12 & $\mathrm{~N}+\mathrm{ART}$ & $\mathrm{ART}+\mathrm{N}$ \\
\hline 13 & $\mathrm{~S}+\mathrm{V}$ & $\mathrm{S}+\mathrm{V}$ \\
\hline 14 & $\mathrm{NUM}+\mathrm{N}$ & $\mathrm{NUM}+\mathrm{N}$ \\
\hline 15 & $\mathrm{AFF}+\mathrm{VS}$ & $\mathrm{VS}+\mathrm{AFF}$ \\
\hline 16 & $\mathrm{~N}+\mathrm{POSS} . \mathrm{AFF}$ & POSS.AFF $+\mathrm{N}$ \\
\hline 17 & $\mathrm{O}+\mathrm{V}$ & $\mathrm{V}+\mathrm{O}$ \\
\hline 18 & $\mathrm{~V}+\mathrm{AUX}$ & $\mathrm{AUX}+\mathrm{V}$ \\
\hline 19 & NEG.AUX+V & NEG.AUX+V \\
\hline 20 & COMPL+S & $\mathrm{COMPL}+\mathrm{S}$ \\
\hline 21 & $\mathrm{~N}+\mathrm{PL}$ & $\mathrm{N}+\mathrm{PL}$ \\
\hline 22 & $\mathrm{~N}+\mathrm{ADJ}$ & $\mathrm{ADJ}+\mathrm{N}$ \\
\hline 23 & $\mathrm{DEM}+\mathrm{N}$ & $\mathrm{DEM}+\mathrm{N}$ \\
\hline 24 & $\mathrm{INT}+\mathrm{ADJ}$ & $\mathrm{INT}+\mathrm{ADJ}$ \\
\hline 25 & NEG.PRT+V & NEG.PRT+V \\
\hline 26 & $\mathrm{PRT}+\mathrm{V}$ & $\mathrm{PRT}+\mathrm{V}$ \\
\hline
\end{tabular}

\section{Conclusion}

In this project we investigated the word order of Persian and English languages by means of the examples driven from the 26 orders which was mainly driven from Dryer (1992) and Dabir Moghaddam (2001). We aimed at finding the probable correlations and diversities between the two languages. We dealt with each language's characteristics and provided three tables that would confirm our explanations. The word order of English and Persian shows a number of differences. Persian has a free word order while English is strictly an SVO language. These differences in the application of adposition, noun and relative clause, want and verb, content verb and auxiliary, question particle and sentence, adverbial subordinator and clause, etc. cause problems for Persian people to learn English or vice versa. This will help learners to be familiar with the word order of these languages. Also, by pointing at the areas of difficulties between the two languages learners can find the most common problems in finding an accurate word order for English or Persian.

\section{Appendix}

List of Abbreviations

\begin{tabular}{|c|c|c|}
\hline 1 & 1 & $1^{\text {st }}$ person \\
\hline 2 & 2 & 2nd person \\
\hline 3 & 3 & $3^{\text {rd }}$ person \\
\hline 4 & ADJ & Adjective \\
\hline 5 & ADP.PH & Adpositional phrase \\
\hline 6 & ART & Article \\
\hline 7 & AUX & Auxiliary \\
\hline 8 & CLIT & Clitic \\
\hline 9 & COMP & Comparative \\
\hline 10 & COMPL & Complementizer \\
\hline 11 & CONT.V & Content verb \\
\hline 12 & COP & Copula \\
\hline 13 & DEM & Demonstrative \\
\hline 14 & EP & Epenthesis \\
\hline 15 & GEN & Genitive \\
\hline 16 & IMP & Imperfect tense \\
\hline 17 & INDEF & Indefinite \\
\hline 18 & INF & Infinitive \\
\hline 19 & INT & Intensifier \\
\hline 20 & M.ADV & Manner adverb \\
\hline 21 & $\mathrm{~N}$ & Noun \\
\hline 22 & NEG & Negative \\
\hline 23 & NEG.AUX & Negative auxiliary \\
\hline 24 & NEG.PRT & Negative particle \\
\hline 25 & NUM & Numeral \\
\hline 26 & $\mathrm{O}$ & Object \\
\hline 27 & $\mathrm{OM}$ & Object marker \\
\hline 28 & PAST & Past tense \\
\hline 29 & PASTP & Past participle \\
\hline 30 & PL & Plural \\
\hline 31 & PM & Past marker \\
\hline 32 & POSS.AFF & Possessive affix \\
\hline 33 & POSTP & Postpositional \\
\hline 34 & PP & Past participle \\
\hline 35 & PRE & Predicate \\
\hline 36 & PREP & Prepositional \\
\hline 37 & PRES & Present \\
\hline 38 & QU.PRT & Question particle \\
\hline 39 & REL.CL & Relative clause \\
\hline 40 & REST & Restrictive \\
\hline 41 & $\mathrm{~S}$ & Sentence \\
\hline 42 & SG & Singular \\
\hline 43 & SUB & Subjunctive \\
\hline 44 & TNS/ASP.AFF & Tense/aspect affix \\
\hline 45 & TNS/ASP.PRT & Tense/aspect particle \\
\hline 46 & V & Verb \\
\hline 47 & V.EL & Verbal element \\
\hline 48 & V.S & Verb stem \\
\hline
\end{tabular}

\section{References}

[1] Dabir Moghadam, M. (2001). Word order typology of Iranian languages. The journal of humanities. 8(2), 17-22.

[2] Dryer, M.S. (1992). The Greenbergian word order correlations. Language, 68, 81-138

[3] Gill, N. S. (2010). Word order: Latin and English differences in word order. London. 
[4] Johnson, S. (2008). Word order. Retrieved 4 July 2012 from http://www.khoaanh .net/index.php?module $=$ News \&func $=v i e$ w\&prop $=$ Topic \& cat $=10032 \&$ page $=4$.

[5] Oranski, Y. (2007). Iranian languages. ( $2^{\text {nd }}$ ed.). Tehran: Sokhan Pubication.

[6] Ramsay, A.M., Ahmed, N., \& Mirzaiean, V. (2005), Persian word-order is free but not (quite) discontinuous, 5th International Conference on Recent Advances in Natural Language Processing (RANLP-05), Borovets, Bulgaria, 412418.
[7] Shoebottom, P. (n. d.). A guide to learning English. Retrieved 2 July 2012 from the World Wide Web: http://esl.fis.edu/grammar/rules/order.htm.

[8] Tallerman, M. (2005). Understanding syntax. ( $2^{\text {nd }}$ ed.). London: Malta.

[9] Wallwork, A. (2011). English for writing research papers. Retrieved 10 September 2012 from the World Wide Web: http://www.springer.com/978-1-4419-7921-6. 